\title{
PENGARUH PERPUTARAN KAS, PERPUTARAN PIUTANG, PERPUTARAN PERSEDIAAN, DAN PERPUTARAN AKTIVA TETAP TERHADAP PROFITABILITAS PADA PERUSAHAAN MANUFAKTUR SEKTOR INDUSTRI DASAR \& KIMIA YANG TERDAFTAR DI BURSA EFEK INDONESIA PERIODE 2016-2019
}

\author{
Widia Praptiwi \\ Fakultas Ekonomi Universitas Krisnadwipayana \\ Jalan Unkris Jatiwaringin Jakarta Timur \\ e-mail: wid7bmt@yahoo.co
}

\begin{abstract}
The research method is done by first determining the object of research, population and sample and data collection techniques. In this research the type used is secondary data. The research method is to use quantitative analysis which analyzes by means of description, classical assumption test, regression analysis and data hypothesis testing using SPSS Version 26 software.The results of this study indicate that Cash Turnover, Receivable Turnover, Inventory Turnoverand Fixed Assets Turnover simultaneously affect Profitability in Industrial and Chemical Manufacturing Companies listed on the Indonesia Stock Exchange (BEI) Period 20162019. While partially Cash Turnover, Inventory Turnover and Fixed Asset Turnover affect Profitability. Meanwhile, the Receivable Turnover has no effect on the profitability of Industrial and Chemical Manufacturing Companies listed on the Indonesia Stock Exchange (BEI) for the period of 2016-2019.
\end{abstract}

Keywords: Profitability, Cash Turnover, Receivable Turnover,Inventory Turnover and Fixed Asset Turnover

\section{PENDAHULUAN}

Setiap perusahaan yang didirikan baik perusahaan dagang, perusahaan jasa, dan perusahaan manufaktur memiliki tujuan yang sama yaitu untuk menghasilkan keuntungan dan menjaga keberlanjutan perusahaan di masa yang akan mendatang. Menurut (Sartono, 2015) Profitabilitas adalah kemampuan perusahaan untuk menghasilkan keuntungan dalam hal penjualan dan total aset. Profitabilitas dinilai sangat penting, karena untuk menarik modal dari luar dan melangsungkan hidup suatu perusahaan haruslah berada dalam keadaan yang menguntungkan. Dalam menilai kinerja suatu perusahaan, keuntungan atau laba perusahaan selalu menjadi perhatian utama para calon investor. Keuntungan atau laba itulah yang nantinya akan digunakan untuk memastikan calon investor, apakah investasi pada suatu perusahaan tersebut akan memberikan keuntungan atau tingkat pengembalian yang diharapkan sesuai atau tidak. Perusahaan dituntut harus mampu mengembangkan organisasi agar dapat mengimplementasikan strategi perusahaan dan dapat melanjutkan kegiatan usahanya. Perusahaan tentu ingin memperolehkeuntungan yang maksimal, sehingga perusahaan dapat bertahanuntuk waktu yang lama. Menurut (Hery, 2015)profitabilitas dapat diukur dengan Return On Asset, Return on Equity, Gross Profit Margin, Operating Profit Margin dan Net Profit Margin. Salah satu rasio profitabilitas yang akan digunakan dalam penelitian ini adalah Return On Asset 
DOI: http://dx.doi.org/10.35137/jabk.v8i2.568

(ROA). Menurut (Hery, 2015)Return On Asset merupakan rasio yang menunjukkan seberapa besar kontribusi aset dalam menghasilkan laba bersih. Dengan mengetahui Return On Asset (ROA), maka perusahaan dapat menilai apakah perusahaan telah efisien dalam menggunakan aktivanya untuk menjalankan kegiatan operasional perusahaan dalam menghasilkan keuntungan dan dapat melihat seberapa baik suatu perusahaan tersebut mampu mengkonversi aset menjadi keuntungan atau laba. Karena semakin tinggi Return On Asset (ROA), maka semakin baik posisi perusahaan tersebut dari segi penggunaan aset dan semakin tinggi pula tingkat keuntungan yang akan dicapai oleh perusahaan. Begitu juga sebaliknya, apabila Return On Asset (ROA) rendah maka posisi perusahaan akan kurang baik dan tingkat keuntungan yang dicapai oleh perusahaan juga akan rendah. Faktor yang dapat mempengaruhi tinggi rendahnya ROA yaitu perputarankas, perputaran piutang, perputaran persediaan, dan perputaran aktiva tetap.

Perputaran kas adalah perbandingan antara penjualan dengan jumlah rata-rata kas (Riyanto, 2014). Tinggi rendahnya tingkat perputaran kas dan besar kecilnya kas, menunjukkan efisiensi penggunaan kas pada perusahaan. Semakin banyak kas yang kurang efektif, maka semakin banyak uang kas yang ada di dalam perusahaan, dan ini bisa berdampak pada profitabilitas. Akan tetapi jika tingkat perputaran kas suatu perusahaan semakin tinggi, maka akan memberikan keuntungan yang tinggi untuk perusahaan. Sama halnya dengan piutang, karena tingkat perputaran piutang sangat berpengaruh terhadap kegiatan operasional dan kelangsungan hidup perusahaan berhubungan dengan perolehan laba yang akan dihasilkan. Maka besarnya
Jurnal Akuntansi dan Bisnis Krisnadwipayana Volume 8 No. 2 (Mei - Agustus) 2021 tingkat perputaran piutang yang dapat mempengaruhi penerimaan dan pengeluaran perlu diketahui oleh perusahaan.

Piutang adalah akibat transaksi yang dilakukan di masa lalu klaim perusahaan atas uang, jasa atau barang dagang kepada pihak lain (Rudianto, 2012). Dalam dunia usaha salah satu cara yang dapat dilakukan untuk mempertahankan pelanggan yaitu dengan melakukan penjualan kredit, hal tersebut dilakukan untuk menghadapi persaingan usaha yang sangat ketat dalam perusahaan. Penjualan kredit tersebut akan menimbulkan piutang, hal tersebut merupakan kegiatan yang terjadi karena adanya penjualan secara kredit barang dagang atau jasa yang dilakukan oleh perusahaan.Tingkat perputaran piutang perusahaan dapat dihitung dengan membagi nilai penjualan dengan rata-rata piutang. Menurut (Hery, 2017b) Semakin kecil modal kerja yang tertanam dalam piutang usaha maka semakin tinggi rasio perputaran piutang usaha dan hal ini berarti semakin baik untuk perusahaan. Dikatakan semakin baik karena piutang usaha dapat ditagih dalam jangka waktu yang relatif semakin singkat dan cepat sehingga perusahaan tidak terlalu lama menunggu dana yang tertanam dalam piutang usaha untuk dapat dicairkan menjadi uang kas.

Persediaan berperan dalam menjalankan aktivitas penjualan pada perusahaan manufaktur, dan persediaan juga merupakan bagian dari komponen aktiva lancar. Pada prinsipnya persediaan memperlancar atau mempermudah jalannya operasi perusahaan yang harus dilakukan secara rutin untuk memproduksi persediaan serta mendistribusikannya kepada konsumen. Dengan adanya pengelolaan persediaan barang yang baik, maka perusahaan dapat segera mengubah 
DOI: http://dx.doi.org/10.35137/jabk.v8i2.568

persediaan yang tersimpan menjadi keuntungan melalui penjualan. Persediaan ini dapat diukur dengan menghitung tingkat perputaran persediaan. Tingkat perputaran persediaan dapat dihitung dengan membagi jumlah harga pokok penjualan dengan rata-rata persediaan yang dimiliki oleh perusahaan. Menurut (Suharli, 2006) Perputaran persediaan memberikan beberapa pengukuran mengenai likuiditas dan kemampuan perusahaan untuk mengkonversikan barang persediaannya menjadi uang secara tepat dan menentukan berapa kali persediaan terjual atau digantikan dengan persediaan yang baru selama satu tahun. Penjualan yang lemah dan persediaan yang berlebihan menunjukkan bahwa perputaran persediaan tersebut rendah. Sedangkan penjualan yang kuat, menunjukkan bahwa perputaran persediaan tersebut tinggi. Kecepatan penjualan yang diiringi dengan laba yang cukup, sangat penting untuk mengukur performa perusahaan dalam menjual persediaan. Perusahaan akan kehilangan kesempatan menghasilkan keuntungan, jika perputaran persediaan berjalan lambat dan menunjukkan lamanya persediaan yang tersimpan di dalam perusahaan, jika hal itu terjadi maka perusahaan tidak dapat memenuhi permintaan konsumen. Apabila kegiatan operasi perusahaan beroperasi pada kapasitas yang rendah, maka persediaan akanterlalu sedikit. Dan apabila perusahaan kurang efektif pada pengelolaannya namun memiliki persediaan yang banyak, maka perputaran persediaan akan rendah sehingga akan mempengaruhi profitabilitas perusahaan.Selain kas, piutang dan persediaan aktiva perusahaan yang digunakan dalam penelitian ini yaitu aset tetap.
Jurnal Akuntansi dan Bisnis Krisnadwipayana Volume 8 No. 2 (Mei - Agustus) 2021

Peran aktiva sangat penting bagi perusahaan dimana semakin tinggi aktiva yang dimiliki oleh perusahaan untuk mendapatkan aliran dana masuk dari pihak luar dan para investor. Aktiva tetap merupakan harta kekayaan perusahaan yang nilainya bersifat material apabila dibandingkan dengan harta kekayaan lainnya. Untuk mengukur sejauh mana perusahaan mengelola aktiva tetap yang dimiliki untuk menghasilkanpenjualan maka perusahaan menggunakan perputaran aset tetap. Tingkat perputaran aktivatetap dapat dihitung dengan membagi jumlah penjualan dengan aset tetap bersih yang dimiliki oleh perusahaan. Rasio perputaran aktiva tetap adalah rasio yang digunakan untuk mengukur berapa kali dana yang ditanamkan dalam aktiva tetap berputar dalam satu periode (Kasmir, 2015). Perputaran aktiva tetap yang semakin meningkat menunjukan bahwa aktiva tetap perusahaan semakin produktif dalam menghasilkan pendapatan (penjualan), sehingga akan memperbesar kemampuan perusahaan dalam menghasilkan laba. Sebaliknya jika perputaran aktiva tetap menurun menunjukan bahwa aktiva tetap perusahaan tidak produktif dalam menghasilkan pendapatan (penjualan), sehingga akan memperkecil kemampuan perusahaan dalam menghasilkan laba.

Pada penelitian ini objek penelitian yang digunakan adalah kelompok perusahaan manufaktur sektor industri dasar dan kimia periode 2016 s/d 2019. Penelitian ini dilakukan pada perusahaan manufaktur sektor industri dasar dan kimia, karena sektor industri dasar dan kimia mewakili unsur yang digunakan dalam kehidupan sehari-hari. Hampir semua barang dari produk perusahaan industri dasar dan kimia, merupakan untuk kebutuhan kehidupan sehari-hari. Sektor industri dasar dan kimia diperkirakan akan 
DOI: http://dx.doi.org/10.35137/jabk.v8i2.568

berkembang pesat, karena sangat berhubungan erat antara satu dengan lainnya maka, yang dimana persediaan yang diolah oleh perusahaaan sektor industri dasar dan kimia tersebut merupakan keperluan konsumen yang dibutuhkan untuk memenuhi keperluan sehari-hari. Berdasarkan Gambar 1 dibawah ini menunjukkan rata-rata Return on Assets (ROA) pada perusahaan manufaktur sektor Industri Dasar dan Kimia periode 2016 sampai dengan 2019 terjadi fluktuasi, dimana pada tahun 2016 Return on Assets (ROA) sebesar 2,04\%, namun ROA pada tahun 2017 mengalami penurunan menjadi $1,83 \%$ kemudian ROA mengalami kenaikan kembali menjadi 4,18\% pada tahun 2018, dan kembali mengalami penurunan pada tahun 2019 menjadi $1,71 \%$. Penurunan ini menunjukan sektor industri dasar dan kimia tidak efisien dalam menggunakan aktivanya untuk menjalankan kegiatan operasional perusahaan dalam menghasilkan keuntungan. Faktor penurunan tersebut mungkin adanya pengaruh perputaran kas, perputaran piutang, perputaran persediaan dan perputaran aktiva tetap terhadap Profitabilitas (Return on Assets).

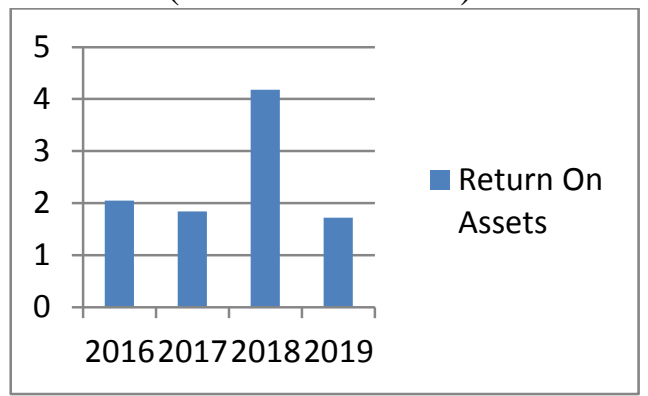

Gambar 1. Return on Assets pada Perusahaan Sektor Industri Dasar dan Kimia yang Terdaftar di BEI Periode 2016-2019

Berdasarkan beberapa penelitian sebelumnya, terdapat beberapa perbedaan hasil penelitian pengaruh perputaran kas terhadap profitabilitas yaitu penelitian
Jurnal Akuntansi dan Bisnis Krisnadwipayana Volume 8 No. 2 (Mei - Agustus) 2021

yang dilakukan (Nurafika, 2018),(Sariningsih, 2018), (Apriliasari, 2018),(Umayta, 2019), (Purwanti, 2019), (Pratama, 2017), (Suminar, 2015), menyatakan bahwa perputaran kas, perputaran persediaan, dan perputaran aktiva tetap berpengaruh terhadapprofitabilitas. Sedangkan penelitian yang dilakukan oleh (Suminar, 2015), (Andari, 2016), (Suhartiningsih, 2012), menyatakan bahwa perputaran kas, perputaran persediaan, dan perputaran aktiva tetap tidak berpengaruh terhadap profitabilitas.

Penelitian ini dilakukan untuk menguji kembali hubungan Perputaran Kas, Perputaran Piutang, Perputaran Persediaan, dan Perputaran Aktiva Tetap terhadap Profitabilitas. Adanya ketidakkonsistenan hasil dari penelitian-penelitian sebelumnya menyebabkan isu ini menarik untuk diteliti kembali. Berdasarkan uraian tersebut di atas maka yang menjadi permasalahan dalam penelitian iniadalah sebagai berikut:

1. Apakah perputaran kas berpengaruh terhadap profitabilitas (Return On Assets) perusahaan manufaktur yang terdaftar di Bursa Efek Indonesia?

2. Apakah perputaranpiutang berpengaruh terhadap profitabilitas (Return On Assets) perusahaan manufaktur yang terdaftar di Bursa Efek Indonesia ?

3. Apakah perputaran persediaan berpengaruh terhadap profitabilitas (Return On Assets) perusahaan manufaktur yang terdaftar di Bursa Efek Indonesia?

4. Apakah perputaranaktiva tetap berpengaruh terhadap profitabilitas (Return On Assets) perusahaan 
DOI: http://dx.doi.org/10.35137/jabk.v8i2.568

manufaktur yang terdaftar di Bursa Efek Indonesia?

5. Apakah perputaran kas, perputaran piutang, perputarab persediaan, dan perputaran aset tetap berpengaruh terhadap profitabilitas (Return On Assets) perusahaan manufaktur yang terdaftar di Bursa Efek Indonesia?

\section{LANDASAN TEORI}

\section{Profitabilitas}

Profitabilitas dinilai sangat penting, karena untuk menarik modal dari luar dan melangsungkan hidup suatu perusahaan haruslah berada dalam keadaan yang menguntungkan. Tanpa keuntungan maka sulit bagi perusahaan untuk keberlanjutan perusahaan di masa depan. Menurut (Kasmir, 2016)Profitabilitas merupakan rasio untuk menilai kemampuan perusahaan dalam mencari keuntungan. Profitabilitas dinilai sangat penting, karena untuk kelangsungan hidup suatu perusahaan haruslah berada dalam keadaan menguntungkan atau profitable.Sedangkan Menurut (Prihadi, 2019)Profitabilitas adalah kemampuan perusahaan dalam menghasilkan keuntungan. Definisi dari keuntungan bisa bermacam-macam, tergantung dari kebutuhan dari pengukuran keuntungan tersebut.

\section{Hasil Pengembalian atas Aset (Return on Assets)}

Hasil pengembalian atas aset merupakan rasio yang menunjukkan seberapa besar kontribusi aset dalam menciptakan laba bersih. Dengan kata lain, rasio ini digunakan untuk mengukur seberapa besar jumlah laba bersih yang akan dihasilkan dari setiap rupiah dana yang tertanam dalam total aset. Rasio ini
Jurnal Akuntansi dan Bisnis Krisnadwipayana Volume 8 No. 2 (Mei - Agustus) 2021 dihitung dengan membagi laba bersih terhadap total aset.

Hasil Pengembalian atas Aktiva

$$
=\frac{\text { Laba Bersih }}{\text { Total Aktiva }}
$$

\section{Perputaran Kas}

Perputaran kas merupakan rasio yang digunakan untuk mengukur tingkat ketersediaan kas untuk membayar biayabiaya yang berkaitan dengan penjualan tagihan (utang) dan biaya-biaya yang berkaitan dengan penjualan. (Kasmir, 2016). Sedangkan menurut (Riyanto, 2014)Perputaran kas merupakan periode berputarnya kas dimulai pada saat dimana kas itu diinvestasikan dalam modal kerja yang tingkat likuiditasnya paling tinggi.Skala pengukuran yang digunakan adalah skala rasio dengan rumus sebagai berikut :

$$
\begin{aligned}
& \text { Perputaran Kas } \\
& =\frac{\text { Penjualan }}{\text { Rata }- \text { Rata Kas }}
\end{aligned}
$$

\section{Perputaran Piutang}

Piutang yang terdapat dalam perusahaan akan selalu dalam keadaan berputar, pengukuran baik tidaknya investasi dalam piutang dan kelancaran penerimaan piutang dapat diketahui dari tingkat perputarannya. Masa-masa penerimaan piutang dari suatu perusahaan selama periode tertentu adalah perputaran piutang. Perputaran piutang akan menunjukkan berapa kali piutang yang timbul sampai piutang tersebut dapat tertagih kembali ke dalam kas perusahaan.Menurut (Sugeng, 2019) Perputaran piutang usaha (account receivable turnover) adalah frekuensi atau berapa kali piutang atau investasi dalam piutang berputar dalam satu periode, misalnya dalam periode satu tahun.Sedangkan Menurut (Kasmir, 
DOI: http://dx.doi.org/10.35137/jabk.v8i2.568

2016)Perputaran piutang merupakan rasio yang digunakan untuk mengukur berapa lama penagihan piutang selama satu periode. Atau berapa kali dana yang ditanam dalam piutang ini berputar dalam satu periode. Makin tinggi rasio menunjukkan bahwa modal kerja yang ditananamkan dalam piutang makin rendah (bandingkan dengan rasio sebelumnya) dan tentunya kondisi ini bagi perusahaan makin baik. Sebaliknya jika rasio ini makin rendah, maka ada over investment dalam piutang. Yang jelas bahwa rasio perputaran piutang memberikan pemahaman tentang kualitas piutang dan kesuksesan penagihan piutang. Rasio perputaran kas ini termasuk ke dalam rasio aktivitas.

\section{Perputaran Piutang$$
=\frac{\text { Penjualan }}{\text { Rata }- \text { Rata Piutang }}
$$

\section{Perputaran Persediaan}

\section{Perputaran}

persediaan menunjukkan berapa kali persediaan diganti (dijual) dalam waktu satu tahun. Dengan demikian, tingkat perputaran persediaan yang tinggi mengindikasikan bahwa tingkat penjualan yang tinggi pada perusahaan. Menurut (Hery, 2017)Perputaran persediaan merupakan rasio yang digunakan untuk mengukur berapa kali dana yang tertanam dalam persediaan akan berputar dalam satu periode atau berapa lama (dalam hari) ratarata persediaan tersimpan digudang hingga akhirnya terjual.Sedangkan Menurut (Kasmir, 2016)Perputaran sediaan merupakan rasio yang digunakan untuk mengukur berapa kali dana yang ditanam dalam sediaan (inventory) ini berputar dalam suatu periode. Perputaran
Jurnal Akuntansi dan Bisnis Krisnadwipayana Volume 8 No. 2 (Mei - Agustus) 2021 persediaan menunjukkan berapa kali persediaan dijual dalam waktu satu tahun.

$$
\begin{aligned}
& \text { Perputaran Persediaan } \\
& =\frac{\text { Harga Pokok Penjualan }}{\text { Rata }- \text { Rata Persediaan }}
\end{aligned}
$$

\section{Perputaran Aktiva Tetap}

Menurut (Hery, 2017)Perputaran aktiva tetap merupakan rasio yang digunakan untuk kefektifan aktiva tetap yang dimiliki oleh perusahaan dalam menghasilkan penjualan atau dengan kata lain untuk mengukur seberapa efektif kapasitas aktiva tetap turut berkontribusi menciptakan penjualan.Sedangkan Menurut (Koesmowidjojo, 2017)Perputaran aktiva tetap adalah rasio yang membandingkan antara penjualan dan total aktiva tetap yang dimiliki organisasi. Semakin tinggi nilai rasio yang didapatkan menunjukkan semakin efektif penggunaan aktiva tetap dalam mendapatkan penghasilan. Untuk menghitung rasio ini, rumus yang digunakan sebagai berikut:

$$
\begin{aligned}
& \text { Perputaran Aktiva Tetap } \\
& =\frac{\text { Penjualan }}{\text { Aktiva Tetap }}
\end{aligned}
$$

\section{Kerangka Konseptual}

Berdasarkan penelitian-penelitian terdahulu, maka peneliti menggambarkan kedalam kerangka penelitian berikut ini :

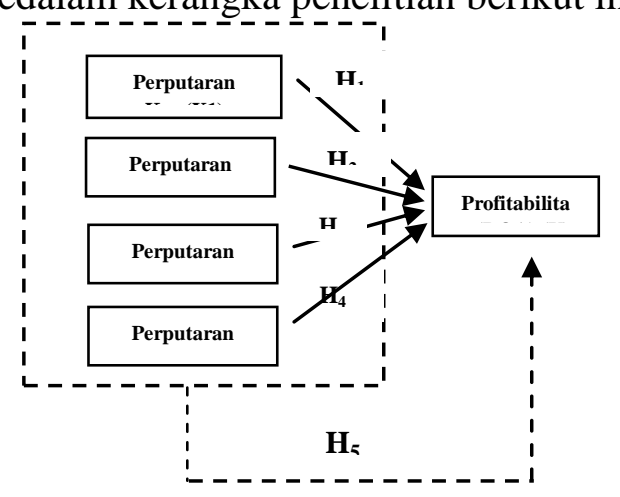

Gambar 2. Kerangka Konseptual 


\section{Pengembangan Hipotesis}

\section{Pengaruh Perputaran Kas Terhadap Profitabilitas}

Menurut (Riyanto, 2014) Semakin tinggi perputaran kas akan semakin baik dalam penggunaan kas dan keuntungan yang diperoleh akan semakin besar. Tingkat perputaran kas merupakan ukuran efisiensi penggunaan kas yang dilakukan oleh perusahaan. Karena tingkat perputaran kas menggambarkan kecepatan kembalinya kas yang telah ditanamkan di dalam modal kerja.Penelitian yang dilakukan oleh (Umayta, 2019),(Nurafika, 2018) dan (Purwanti, 2019) mengenai pengaruh perputaran kas terhadap profitabilitas yang menyatakan bahwa perputaran kas berpengaruh terhadap profitabilitas. Teori dan hasil penelitian ini membuktikan bahwa semakin tinggi perputaran kas maka profitabilitas juga semakin tinggi.

H1 : Perputaran kas berpengaruh positif terhadap profitabilitas.

\section{Pengaruh Perputaran Piutang Terhadap Profitabilitas}

Pengaruh perputaran piutang terhadap Return On Asset (ROA) menurut (Sugeng, 2019) menyatakan semakin tinggi frekuensi perputaran piutang atau semakin cepat piutang berputar menunjukkan semakin efektif dan efisien pengelolaan investasi dalam piutang. Dikatakan semakin efektif dan efisien karena piutang usaha dapat ditagih dalam jangka waktu yang relatif semakin singkat dan cepat sehingga perusahaan tidak terlalu lama menunggu dana yang tertanam dalam piutang usaha untuk dapat dicairkan.Penelitian yang dilakukan (Pratama, 2017), (Suminar, 2015),
Jurnal Akuntansi dan Bisnis Krisnadwipayana Volume 8 No. 2 (Mei - Agustus) 2021 (Sariningsih, 2018), dan (Purwanti, 2019)yang mengenai pengaruh perputaran piutang terhadap Return On Assets (ROA) yang menyatakan bahwa, perputaran persediaan berpengaruh terhadap Return On Assets (ROA). Teori dan hasil penelitian ini membuktikan yaitu semakin tinggi perputaran piutang maka Return On Assets (ROA) juga semakin tinggi.

H2 : Perputaran piutang berpengaruh positif dan signifikan terhadap Return On Assets (ROA).

\section{Perputaran Persediaan Terhadap Profitabilitas}

Pengaruh perputaran persediaan terhadap Return On Asset (ROA) menurut (Munawir, 2016) menyatakan bahwa semakin tinggi tingkat perputaran persediaan akan memperkecil resiko terhadap kerugian yang disebabkan karena penurunan harga, disamping itu akan menghemat biaya penyimpanan dan pemeliharaan terhadap persediaan tersebut.Penelitian yang dilakukan oleh (Suminar, 2015), (Nurafika, 2018), (Sariningsih, 2018), (Purwanti, 2019) yang mengenai pengaruh perputaran persediaan terhadap Return On Assets (ROA) yang menyatakan bahwa, perputaran persediaan berpengaruh terhadap Return On Assets (ROA). Teori dan hasil penelitian ini membuktikan yaitu semakin tinggi perputaran persediaan maka Return On Assets (ROA) juga semakin tinggi.Dapat disimpulkan bahwa, perputaran persediaan mempunyai pengaruh terhadap Return On Assets (ROA). Artinya, jika perputaran persediaan naik maka Return On Assets (ROA) juga akan naik. Dan sebaliknya, jika perputaran persediaan turun maka Return On Assets (ROA) juga akan turun.

H3 : Perputaran persediaan berpengaruh positif terhadap Return On Assets (ROA). 
Jurnal Akuntansi dan Bisnis Krisnadwipayana Volume 8 No. 2 (Mei - Agustus) 2021

\section{Pengaruh Perputaran Aktiva Tetap Terhadap Profitabilitas}

Menurut (Koesmowidjojo, 2017) semakin tinggi nilai rasio yang didapatkan menunjukkan semakin efektif penggunaan aktiva tetap dalam mendapatkan penghasilan. Perusahaan yang memiliki Rasio Perputaran Aktiva Tetap atau Aset Tetap yang tinggi menunjukan bahwa perusahaan tersebut mampu untuk mengelola aset tetapnya secara efisien dan efektif. Aset tetap sangat penting untuk diperhitungkan karena aset tetap ini merupakan komponen terbesar dari total aset perusahaan.Penelitian yang dilakukan oleh (Suhartiningsih, 2012) dan (Apriliasari, 2018) mengenai pengaruh perputaran aktiva tetap terhadap Return On Assets (ROA) menyatakan bahwa, perputaran aktiva tetap berpengaruh terhadap Return On Assets (ROA). Teori dan hasil penelitian ini membuktikan yaitu semakin tinggi perputaran aktiva tetap maka Return On Assets (ROA) juga semakin tinggi.

H4 : Perputaran aktiva tetap berpengaruh positif terhadap Return On Assets (ROA).

\section{Pengaruh Perputaran Kas, Perputaran Piutang, Perputaran Persediaan, dan Perputaran Aktiva Tetap Terhadap Profitabilitas}

Berdasarkan penelitian yang dilakukan oleh (Suhartiningsih, 2012), (Andari, 2016) dan (Apriliasari, 2018) mengenai pengaruh perputaran kas, perputaran piutang, perputaran persediaan dan perputaran aktiva tetap terhadap profitabilitas (ROA) menyatakan bahwa perputaran kas, perputaran piutang, perputaran persediaan dan perputaran aktiva tetap berpengaruh dan signifikan terhadap profitabilitas (ROA).
H5 : Perputaran kas, perputaran piutang, perputaran persediaan dan perputaran aktiva tetap berpengaruh dan signifikan terhadap Return On Assets (ROA).

\section{METODE PENELITIAN}

\section{Objek, Lokasi dan Waktu Penelitian}

Penelitian ini dilakukan pada Bursa Efek Indonesia yang menyediakan data laporan keuangan perusahaan yang sudah go public dengan mengakses sistem resmi Bursa Efek Indonesia yaitu www.idx.co.id. Objek dalam penelitian ini adalah Perusahaan Manufaktur Sektor Industri Dasar danKimia yang terdaftar di Bursa Efek Indonesia periode 2016 s/d 2019.

\section{Variabel dan Pengukurannya}

Variabel didalam penelitian ini terdiri dari variabel independen atau variabel bebas, variabel dependen atau variabel terikat.

Tabel 1. Operasional Variabel

\begin{tabular}{|c|c|c|}
\hline Variabel & $\begin{array}{c}\text { Indikato } \\
\mathbf{r}\end{array}$ & Formula \\
\hline $\begin{array}{c}\text { Profitabilita } \\
\text { s }\end{array}$ & ROA & $\begin{array}{l}\text { Hasil Pengembalian atas Aktiva } \\
=\frac{\text { Laba Bersih }}{\text { Total Aktiva }}\end{array}$ \\
\hline $\begin{array}{l}\text { Perputaran } \\
\text { Kas }\end{array}$ & СТO & $\begin{array}{l}\text { Perputaran Kas } \\
=\frac{\text { Penjualan }}{\text { Rata }- \text { Rata Kas }}\end{array}$ \\
\hline $\begin{array}{l}\text { Perputaran } \\
\text { Piutang }\end{array}$ & RTO & $\begin{array}{l}\text { Perputaran Piutang } \\
=\frac{\text { Penjualan }}{\text { Rata }- \text { Rata Piutang }}\end{array}$ \\
\hline $\begin{array}{l}\text { Perputaran } \\
\text { Persediaan }\end{array}$ & ITO & $\begin{array}{l}\text { Perputaran Persediaan } \\
=\frac{\text { Harga Pokok Penjualan }}{\text { Rata-Rata Persediaan }}\end{array}$ \\
\hline $\begin{array}{l}\text { Perputaran } \\
\text { Aktiva } \\
\text { Tetap }\end{array}$ & FATO & $\begin{array}{l}\text { Perputaran Aktiva Tetap } \\
=\frac{\text { Penjualan }}{\text { Aktiva Tetap }}\end{array}$ \\
\hline
\end{tabular}

350 


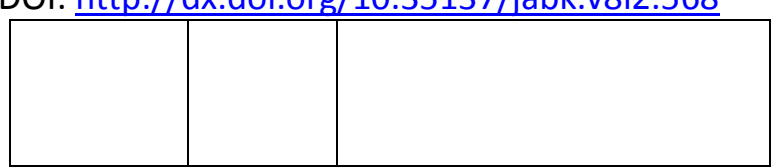

\section{Populasi dan Sampel}

Populasi dari penelitian ini adalah seluruh perusahaan manufaktur sektor industri dasar \& kimia yang terdaftar di Bursa Efek Indonesia pada 31 Desember (tahun 2016 - 2019) yang berjumlah 78 Perusahaan. Sampel penelitian yang diambil sebanyak 25 perusahaan manufaktur yang terdaftar di Bursa Efek Indonesia (BEI) yang bergerak dalam bidang sektor industri dasar \& kimia pada 31 Desember tahun 2016-2019 yang dipilih dengan metode purposive sampling.

Tabel 2. Kriteria Sampel

\begin{tabular}{|c|c|c|}
\hline No & Keterangan & Jumlah \\
\hline 1 & $\begin{array}{c}\text { Perusahaan Manufaktur Sektor Industri } \\
\text { Dasar \& Kimia yang Terdaftar di Bursa } \\
\text { Efek Indonesia Tahun 2016 - 2019 }\end{array}$ & 78 \\
\hline 2 & $\begin{array}{c}\text { Perusahaan yang tidak menerbitkan } \\
\text { laporan keuangan secara lengkap } \\
\text { selama 3 tahun berturut-turut dari tahun } \\
\text { 2016 - 2019 }\end{array}$ & (44) \\
\hline 3 & $\begin{array}{c}\text { Perusahaan Sektor Industri Dasar dan } \\
\text { Kimia yang tidak mengalami kerugian } \\
\text { dalam laporan keuangan selama tahun } \\
\text { pengamatan. }\end{array}$ & (8) \\
\hline 4 & $\begin{array}{c}\text { Perusahan yang tidak menampilkan } \\
\text { data-data laporan keuangan berupa total } \\
\text { penjualan bersih, total kas, total piutang } \\
\text { usaha, total harga pokok persediaan, } \\
\text { total persediaan, total aktiva dan total } \\
\text { laba setelah pajak yang dibutuhkan } \\
\text { dalam penelitian. }\end{array}$ & (1) \\
\hline & $\begin{array}{c}\text { Jumlah sampel perusahaan yang } \\
\text { memenuhi kriteria }\end{array}$ & $\mathbf{2 5}$ \\
\hline
\end{tabular}

\section{Metode Analisis Data}

Pengujian hipotesis baik hiotesis pertama, kedua, dan hipotesis ketiga dilakukan dengan Moderated Regression Analysis (MRA). Untuk pengujian hipotesis pertama, kedua, ketiga dan
Jurnal Akuntansi dan Bisnis Krisnadwipayana Volume 8 No. 2 (Mei - Agustus) 2021 keempat pada penelitian ini dilakukan dengan model regresi sebagai berikut : $\mathbf{Y}=\alpha+\beta_{1} X_{1}+\beta_{2} X_{2}+\beta_{3} X_{3}+\beta_{4} X_{4}+\varepsilon$

Keterangan :

$\begin{array}{ll}\mathrm{Y} & =\text { Return On Assets (ROA) } \\ \alpha & =\text { konstanta } \\ \beta_{1}, \beta_{2}, \beta_{3}, \beta_{4}=\text { koefisien regresi } \\ \mathrm{x} 1 & =\text { perputaran kas } \\ \mathrm{x} 2 & =\text { perputaran piutang } \\ \mathrm{x} 3 & =\text { perputaran persediaan } \\ \mathrm{x} 4 & =\text { perputaran aktiva tetap } \\ \varepsilon & =\text { Kesalahan residu (error) }\end{array}$

\section{HASIL PENELITIAN DAN PEMBAHASAN}

Penelitian ini menggunakan data sekunder 25 (dua puluh lima) perusahaan yang masuk dalam 78perusahaan manufaktur sektor industri dasar \& kimia yang terdaftar di Bursa Efek Indonesia pada tahun 2016 -201, sehingga diperoleh sebanyak 48 data observasi yang dijadikan sampel penelitian dan sesuai dengan kriteria yang telah ditetapkan.

\begin{tabular}{|c|c|c|c|c|c|}
\hline \multicolumn{6}{|c|}{ Descriptive Statistics } \\
\hline & $\mathrm{N}$ & $\begin{array}{c}\text { Minimu } \\
\mathrm{m}\end{array}$ & $\begin{array}{c}\text { Maximu } \\
\mathrm{m}\end{array}$ & Mean & $\begin{array}{c}\text { Std. } \\
\text { Deviatio } \\
\mathrm{n}\end{array}$ \\
\hline $\begin{array}{l}\text { CTO } \\
(\mathrm{X} 1)\end{array}$ & $\begin{array}{l}4 \\
8 \\
\end{array}$ & 1,0441 & 16,1387 & $\begin{array}{r}5,7907 \\
01 \\
\end{array}$ & $\begin{array}{r}3,72594 \\
10 \\
\end{array}$ \\
\hline $\begin{array}{l}\text { RTO } \\
\text { (X2) }\end{array}$ & $\begin{array}{l}4 \\
8\end{array}$ & ,9138 & 14,3173 & $\begin{array}{r}5,8113 \\
25\end{array}$ & $\begin{array}{r}3,55901 \\
57\end{array}$ \\
\hline $\begin{array}{l}\text { ITO } \\
\text { (X3) }\end{array}$ & $\begin{array}{l}4 \\
8\end{array}$ & 1,0222 & 7,0713 & $\begin{array}{r}3,3442 \\
06\end{array}$ & $\begin{array}{r}1,50665 \\
88\end{array}$ \\
\hline $\begin{array}{l}\text { FATO } \\
(\mathrm{X} 4)\end{array}$ & $\begin{array}{l}4 \\
8 \\
\end{array}$ & ,3915 & 2,6980 & $\begin{array}{r}1,3790 \\
52 \\
\end{array}$ & $\begin{array}{r}, 607437 \\
3\end{array}$ \\
\hline $\begin{array}{l}\text { ROA } \\
(Y)\end{array}$ & $\begin{array}{l}4 \\
8\end{array}$ &, 0031 & ,1284 & $\begin{array}{r}04613 \\
7\end{array}$ & $\begin{array}{r}, 030034 \\
5\end{array}$ \\
\hline $\begin{array}{l}\text { Valid N } \\
\text { (listwis } \\
\text { e) }\end{array}$ & 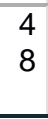 & & & & \\
\hline
\end{tabular}

Tabel 3. Hasil Uji Statistik Deskriptif Varibel 
Variabel Perputaran Kas (X1) Pada Perusahaan Manufaktur Sektor Industri Dasar dan Kimia Periode 20162019

Variabel ini menghasilkan nilai minimum 1,0441, nilai maksimum 16,1387 , nilai mean 5,790701, dengan nilai standar deviasi 3,7259410 dan dengan jumlah pengamatan sebanyak 48data. Rasio Perputaran Kas perusahaan manufaktur yang menjadi data pengamatan dalam penelitian ini berkisar antara 1,0441 sampai 16,1387, dengan nilai ratarata5,790701,pada standar deviasi3,7259410. Rasio Perputaran Kas tertinggi terjadi pada PT Suparma Tbk pada tahun 2016 yaitu sebesar 16,13870407. Sedangkan Rasio Perputaran Kas terendah terjadi pada PT Indocement Tunggal Prakarsa Tbk pada tahun 2017 sebesar 1,04411508.Nilai rata-rata lebih besar dari standar deviasi yaitu5,790701>3,7259410. Hal ini menunjukkan bahwa tidak terjadi penyimpangan pada variabel Perputaran Kas karena nilai mean lebih besar dari standar deviasi. Hal ini menggambarkan bahwa nilai perputaran kas sampel perusahaan sektor industri dasar dan kimia dalam penelitian ini tidak terlalu bervariasi sehingga dapat disimpulkan bahwa nilai mean dapat mempresentasikan keseluruhan nilai Perputaran Kas.

\section{Variabel Perputaran Piutang (X2) Pada Perusahaan Manufaktur Sektor Industri Dasar dan Kimia Periode 2016- 2019}

Variabel ini menghasilkan nilai
minimum 0,9138, nilai maksimum
14,3173, mean 5,811325, dengan nilai
standar deviasi3,5590157 dan dengan
jumlah pengamatan sebanyak 48data.

Jurnal Akuntansi dan Bisnis Krisnadwipayana Volume 8 No. 2 (Mei - Agustus) 2021

Rasio Perputaran Piutang perusahaan manufaktur yang menjadi data pengamatan dalam penelitian ini berkisar antara 0,9138 sampai 14,3173 , dengan nilai ratarata5,811325, pada standar deviasi3,5590157. Rasio Perputaran Piutang tertinggi terjadi pada PT Emdeki Utama Tbk pada tahun 2019 yaitu sebesar 14,3173, sedangkan Rasio Perputaran Piutang terendah terjadi pada PT Waskita Beton Precast Tbk pada tahun 2018 sebesar 0,9138.Nilai rata-rata lebih besar dari standar deviasi yaitu5,811325>3,5590157. Hal ini menunjukkan bahwa tidak terjadi penyimpangan pada variabel Perputaran Piutang karena nilai mean lebih besar dari standar deviasi. Hal ini menggambarkan bahwa nilai perputaran piutang sampel perusahaan sektor industri dasar dan kimia dalam penelitian ini tidak terlalu bervariasi sehingga dapat disimpulkan bahwa nilai mean dapat mempresentasikan keseluruhan nilai Perputaran Piutang.

Variabel Perputaran Persediaan (X3) Pada Perusahaan Manufaktur Sektor Industri Dasar dan Kimia Periode 20162019

Variabel ini menghasilkan nilai minimum1,0222, nilai maksimum7,0713, mean3,344206, dengan nilai standar deviasi1,5066588 dan dengan jumlah pengamatan sebanyak 48 data.Rasio Perputaran Persediaan perusahaan manufaktur yang menjadi data pengamatan dalam penelitian ini berkisar antara 1,0222sampai 7,0713, dengan nilai ratarata3,344206, pada standar deviasi1,5066588. Rasio Perputaran Persediaan tertinggi terjadi pada Arwana Citramulia Tbk pada tahun 2018 yaitu sebesar 7,0713, sedangkan Rasio Perputaran Piutang terendah terjadi pada PT Impack Pratama Industri Tbk pada 
DOI: http://dx.doi.org/10.35137/jabk.v8i2.568 tahun 2016 sebesar 1,0222. Nilai rata-rata lebih besar dari standar deviasi yaitu3,344206>1,5066588. Hal ini menunjukkan bahwa tidak terjadi penyimpangan pada variabel Perputaran Persediaan karena nilai mean lebih besar dari standar deviasi. Hal ini menggambarkan bahwa nilai perputaran persediaan sampel perusahaan sektor industri dasar dan kimia dalam penelitian ini tidak terlalu bervariasi sehingga dapat disimpulkan bahwa nilai mean dapat mempresentasikan keseluruhan nilai Perputaran Persediaan.

\section{Variabel Perputaran Aktiva Tetap (X4) Pada Perusahaan Manufaktur Sektor Industri Dasar dan Kimia Periode 2016- 2019}

Variabel ini menghasilkan nilai minimum 0,3915, nilai maksimum2,6980, mean1,379052, dengan nilai standar deviasi0,6074373 dan dengan jumlah pengamatan sebanyak 48 data.Rasio Perputaran Aktiva Tetap pada perusahaan manufaktur yang menjadi data pengamatan dalam penelitian ini berkisar antara 0,3915 sampai 2,6980 , dengan nilai ratarata1,379052, pada standar deviasi 0,6074373. Rasio Perputaran Aktiva Tetap tertinggi terjadi pada Surya Toto Indonesia Tbk pada tahun 2017 yaitu sebesar 2,6980, sedangkan Rasio Perputaran Piutang terendah terjadi pada PT Aneka Gas Industri Tbk pada tahun 2016 sebesar 0,3915. Nilai rata-rata lebih besar dari standar deviasi yaitu 1,379052>0,6074373. Hal ini menunjukkan bahwa tidak terjadi penyimpangan pada variabel Perputaran Aktiva Tetap karena nilai mean lebih besar dari standar deviasi. Hal ini menggambarkan bahwa nilai perputaran aktiva tetap sampel perusahaan sektor industri dasar dan kimia dalam penelitian
Jurnal Akuntansi dan Bisnis Krisnadwipayana Volume 8 No. 2 (Mei - Agustus) 2021 ini tidak terlalu bervariasi sehingga dapat disimpulkan bahwa nilai mean dapat mempresentasikan keseluruhan nilai Perputaran Aktiva Tetap.

Variabel Profitabilitas (Y) Pada Perusahaan Manufaktur Sektor Industri Dasar dan Kimia Periode 20162019

Variabel ini menghasilkan nilai minimum0,0031, nilai maksimum0,1284, mean0,046137, dengan nilai standar deviasi0,0300345 dan dengan jumlah pengamatan sebanyak 48 data..

Rasio Profitabilitas perusahaan manufaktur yang menjadi data pengamatan dalam penelitian ini berkisar antara 0,0031sampai 0,1284 , dengan nilai rata-rata0,046137, pada nilai standar deviasi 0,0300345 . Rasio Profitabilitas tertinggi terjadi pada PT Indocement Tunggal Prakarsa Tbk pada tahun 2016 sebesar 0,1284, sedangkan Rasio Profiabilitasterendah terjadi pada PT Pabrik Kertas Tjiwi Kimia Tbk pada tahun 2016 yaitu sebesar 0,0031.Nilai rata-rata lebih besar dari standar deviasi yaitu 0,046137>0,0300345. Hal ini menunjukkan bahwa tidak terjadi penyimpangan pada variabel Profitabilitas karena nilai mean lebih besar dari standar deviasi. Hal ini menggambarkan bahwa nilai profitabilitas sampel perusahaan sektor industri dasar dan kimia dalam penelitian ini tidak terlalu bervariasi sehingga dapat disimpulkan bahwa nilai mean dapat mempresentasikan keseluruhan nilai Profitabilitas. 


\section{Uji Normalitas}

\section{One-Sample Kolmogorov- Smirnov Test}

\begin{tabular}{llr} 
& & \multicolumn{1}{c}{$\begin{array}{c}\text { Unstandardized } \\
\text { Residual }\end{array}$} \\
\hline $\mathrm{N}$ & & 48 \\
\hline Normal & Mean &, 0000000 \\
\hline & & \\
\cline { 2 - 3 } & Std. &, 02492855 \\
\hline Most Extremeters & Deviation & Absolute \\
Differences & &, 143 \\
\cline { 2 - 3 } & Positive &, 143 \\
\cline { 2 - 3 } & Negative &,- 085 \\
\hline Test Statistic & &, 143 \\
& & \\
\hline Asymp. Sig. (2-tailed) &, $015^{c}$ \\
\hline
\end{tabular}

b. Calculated from data.

c. Lilliefors Significance Correction.

Tabel 4. Hasil Uji Normalitas

Hasil perhitungan statistik dengan uji normalitas menghasilkan nilai Asymp.Sig dari One Sample KolmogorovSmirnovTest $0.015^{c}<\quad 0,05$ artinya $\mathrm{H} 0$ ditolak, sehingga menghasilkan model regresi tidak berdistribusi normal.

\section{Uji Multikolenieritas}

Tabel 5. Hasil Uji Multikolineritas

\begin{tabular}{|c|c|c|c|c|c|c|c|}
\hline & & & Coefficient & & & & \\
\hline & $\begin{array}{l}\text { Unst } \\
\text { Coe }\end{array}$ & $\begin{array}{l}\text { Indardi } \\
\text { ed } \\
\text { icients }\end{array}$ & $\begin{array}{l}\text { Standardi } \\
\text { zed } \\
\text { Coefficien } \\
\text { ts }\end{array}$ & & & $\begin{array}{r}\text { Colline } \\
\text { Statis }\end{array}$ & $\begin{array}{l}\text { arity } \\
\text { cs }\end{array}$ \\
\hline Model & $\mathrm{B}$ & $\begin{array}{l}\text { Std. } \\
\text { Error }\end{array}$ & & $\mathrm{t}$ & $\begin{array}{l}\text { Si } \\
\text { g. }\end{array}$ & $\begin{array}{c}\text { Tolera } \\
\text { nce }\end{array}$ & VIF \\
\hline $\begin{array}{l}1 \text { (Consta } \\
\text { nt) }\end{array}$ & $\begin{array}{r}00 \\
8\end{array}$ &, 014 & & $\begin{array}{r}, 61 \\
9\end{array}$ & $\begin{array}{r}, 5 \\
39\end{array}$ & & \\
\hline $\begin{array}{l}\text { CTO } \\
\text { (X1) }\end{array}$ & $\begin{array}{r}- \\
-00 \\
2\end{array}$ & ,001 &,- 278 & $\begin{array}{r}- \\
2,0 \\
66\end{array}$ & $\begin{array}{l}, 0 \\
45\end{array}$ & ,887 & $\begin{array}{l}1,1 \\
27\end{array}$ \\
\hline $\begin{array}{l}\text { RTO } \\
\text { (X2) }\end{array}$ & $\begin{array}{r}, 00 \\
0\end{array}$ & ,001 &,- 021 & $\begin{array}{r}- \\
, 16 \\
0\end{array}$ & $\begin{array}{r}, 8 \\
73\end{array}$ & ,953 & $\begin{array}{r}1,0 \\
49\end{array}$ \\
\hline $\begin{array}{l}\text { ITO } \\
\text { (X3) }\end{array}$ & $\begin{array}{r}, 00 \\
6 \\
\end{array}$ & ,003 & ,302 & $\begin{array}{r}2,3 \\
61 \\
\end{array}$ & $\begin{array}{l}, 0 \\
23\end{array}$ & ,978 & $\begin{array}{l}1,0 \\
23\end{array}$ \\
\hline $\begin{array}{l}\text { FATO } \\
(\mathrm{X} 4)\end{array}$ & $\begin{array}{r}, 02 \\
3 \\
\end{array}$ & ,007 & ,462 & $\begin{array}{r}3,4 \\
73 \\
\end{array}$ & $\begin{array}{r}0 \\
01 \\
\end{array}$ & 907 & $\begin{array}{r}1,1 \\
03 \\
\end{array}$ \\
\hline
\end{tabular}

Hasil dari perhitungan statistik yang tampak pada tabel 5 diketahui bahwa nilai tolerance dan VIF untuk X1 sebesar 0,887 dan 1,127; nilai tolerance dan VIF untuk X2 sebesar 0,953 dan 1,049; nilai tolerance dan VIF untuk X3 sebesar 0,978 dan 1,023; nilai tolerance dan VIF untuk X4 sebesar 0,907 dan 1,103. Sehingga seluruh variable independen pada persamaan regresi mempunyai nilai tolerance $>0,1$ dan VIF $<10$. Dengan demikian dapat dikatakan tidak ada multikolinearitas, Ho diterima, artinya Tidak ada Multikolinearitas.

\section{Uji Heteroskedastisitas}

Tabel 6. Hasil Uji Glesjer

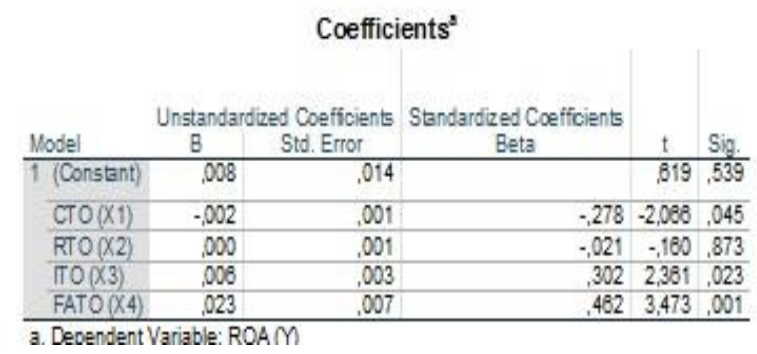


Hasil dari perhitungan statistik yang tampak pada tabel 6 menjelaskan bahwa tidak ada satupun variabel independen yang signifikan secara statistik mempengaruhi nilai Absolut Residual (ABS_RES1). Hal ini dilihat dari probabilitas signifikansinya di atas 0,05. Jadi dapat disimpulkan model regresi tidak mengandung adanya Heteroskedastisitas.

\section{Uji Autokorelasi}

Tabel 7. Hasil Uji Autokorelasi

Berdasarkan pengujianAutokorelasi menggunakan SPSS, didapatkan hasil pengujian Durbin-Watson dengan nilai $1,718(\mathrm{n}=48, \mathrm{k}=4, \mathrm{dl}=1.3619, \mathrm{du}=$ 1.7206) $(4-\mathrm{dl}=2.6381)$ dan $(4-\mathrm{du}=$ 2.2794). Hasil pengujian ini menunjukkan bahwa nilai Durbin-Watson $1.3619<1.718$ $<1.7206$ berada pada area tidak ada autokorelasi positif atau tidak dapat mengambil kesimpulan.Karena nilai Durbin-Watsonberada pada daerah $\mathrm{dl}<\mathrm{dw}<\mathrm{du}$.

\section{Analisis Regresi Linier Berganda}

Tabel 8. Hasil Uji Analisis Regresi Linier Berganda

Berikut penulisan persamaan regresi berdasarkan tabel 8 dari datayang telah diolah dalam penelitian ini:

$$
\begin{gathered}
Y=0,008-0,002 \mathrm{CTO}+0,000 \mathrm{RTO}+ \\
\text { 0,006 ITO + 0,023 FATO }+e
\end{gathered}
$$

1. Konstanta sebesar 0,008 artinya jika nilai CTO, RTO, ITOdan FATO dianggap konstan, maka nilai dari Ysebesar 0,008.

2. $\beta 1=-0,002$, setiap kenaikan $1 \mathrm{x}$ perputaran kas, maka profitabilitas akan mengalami penurunan $0,2 \%$
Jurnal Akuntansi dan Bisnis Krisnadwipayana

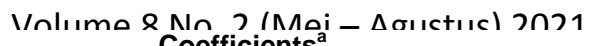

\begin{tabular}{|c|c|c|c|c|c|}
\hline \multirow[b]{3}{*}{ Model } & & & \multirow{3}{*}{$\begin{array}{l}\text { Standardize } \\
d \\
\text { Coefficients } \\
\text { Beta }\end{array}$} & \multirow[b]{3}{*}{$t$} & \multirow[b]{3}{*}{ Sig. } \\
\hline & \multicolumn{2}{|c|}{$\begin{array}{l}\text { Unstandardize } \\
\text { d Coefficients }\end{array}$} & & & \\
\hline & $B$ & $\begin{array}{l}\text { Std. } \\
\text { Error }\end{array}$ & & & \\
\hline 1 ) (Constant & 013 & ,008 & & $\begin{array}{r}1,56 \\
8\end{array}$ & $\begin{array}{r}, 12 \\
4\end{array}$ \\
\hline CTO (X1) & ,001 & ,001 &,- 119 &,- 754 & $\begin{array}{r}45 \\
5\end{array}$ \\
\hline RTO (X2) & ,000 & ,001 &,- 025 &,- 167 & $\begin{array}{r}86 \\
8\end{array}$ \\
\hline ITO (X3) & ,002 & ,002 & ,201 & $\begin{array}{r}1,34 \\
0\end{array}$ & $\begin{array}{r}, 18 \\
7\end{array}$ \\
\hline $\begin{array}{l}\text { FATO } \\
(\mathrm{X} 4)\end{array}$ & ,002 & ,004 & ,066 & ,426 & $\begin{array}{r}, 67 \\
2 \\
\end{array}$ \\
\hline
\end{tabular}
Coefficients

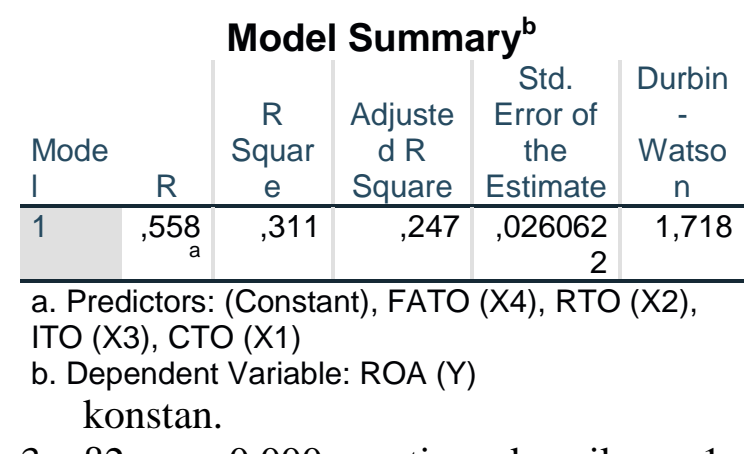

3. $\beta 2=0,000$, setiap kenaikan $1 \mathrm{x}$ perputaran piutang, maka profitabilitas akan mengalami kenaikan 0\% dengan dugaan variabel lainnya konstan.

4. $\beta 3=0,006$, setiap kenaikan $1 \mathrm{x}$ perputaran persediaan, maka profitabilitas mengalami kenaikan $0,6 \%$ dengan dugaan variabel lainnya konstan

5. $\beta 4=0,023$, setiap kenaikan $1 \mathrm{x}$ perputaran aktiva tetap, maka profitabilitas mengalami kenaikan2,3\% dengan dugaan variabel lainnya konstan

\section{Uji Hipotesis}

\section{Uji t (Uji Parsial)}

Berdasarkan tabel 8 hasil uji t, maka hasilnya dapat dijabarkan sebagai berikut: $\mathbf{H}_{1}=$ Perputaran Kas berpengaruh positif terhadap Profitabilitas 
DOI: http://dx.doi.org/10.35137/jabk.v8i2.568

Hasil perhitungan statistik secara parsial yang terlihat pada tabel 8 adalah sesuai dengan pernyataan hipotesis bahwa perputaran kas sebagai variabel independen berpengaruh dan signifikan terhadap profitabilitas, dengan nilai koefisien -2,066 dan dengan nilai signifikansi $0,045<0,05$, artinya perputaran kas berpengaruh negatif dan signifikan terhadap profitabilitas. Hasil penelitian menyatakan bahwa $\mathrm{H}_{1}$ diterima.

$\mathrm{H}_{2}=$ Perputaran Piutang berpengaruh positif terhadap Profitabilitas

Hasil perhitungan statistik secara

\begin{tabular}{|c|c|c|c|c|c|}
\hline \multicolumn{6}{|c|}{ ANOVA $^{a}$} \\
\hline Model & $\begin{array}{c}\text { Sum of } \\
\text { Square } \\
\mathrm{s}\end{array}$ & df & $\begin{array}{c}\text { Mean } \\
\text { Squar } \\
\mathrm{e} \\
\end{array}$ & $\mathrm{F}$ & Sig. \\
\hline $\begin{array}{ll}1 & \text { Regressio } \\
\mathrm{n}\end{array}$ & 013 & 4 & ,003 & $\begin{array}{r}4,85 \\
5 \\
\end{array}$ &, 003 \\
\hline Residual & ,029 & $\begin{array}{l}4 \\
3\end{array}$ & ,001 & & \\
\hline Total & ,042 & $\begin{array}{l}4 \\
7 \\
\end{array}$ & & & \\
\hline
\end{tabular}

a. Dependent Variable: ROA (Y)

b. Predictors: (Constant), FATO (X4), RTO (X2), ITO (X3), CTO (X1)

parsial yang terlihat pada tabel 8 adalah tidak sesuai dengan pernyataan hipotesis bahwa perputaran piutang sebagai variabel independen berpengaruh dan signifikan terhadap profitabilitas, dengan nilai koefisien senilai $-0,160$ dan dengan nilai signifikansi $0,873>0,05$, artinya perputaran piutang berpengaruh negatif dan tidak signifikan terhadap profitabilitas. Hasil penelitian menyatakan bahwa $\mathbf{H}_{2}$ ditolak.

\section{$\mathbf{H}_{3}=$ Perputaran Persediaan berpengaruh positif terhadap Profitabilitas}

Hasil perhitungan statistik secara parsial yang terlihat pada tabel 8 adalah sesuai dengan pernyataan hipotesis bahwa perputaran persediaan sebagai variabel
Jurnal Akuntansi dan Bisnis Krisnadwipayana Volume 8 No. 2 (Mei - Agustus) 2021 independen berpengaruh dan signifikan terhadap profitabilitas, dengan nilai koefisien 2,361 dan dengan nilai signifikansi $0,023<0,05$, artinya perputaran persediaan berpengaruh positif dan signifikan terhadap profitabilitas. Hasil penelitian menyatakan bahwa $\mathrm{H}_{3}$ diterima.

\section{$\mathbf{H}_{4}=$ Perputaran Aktiva Tetap berpengaruh positif terhadap Profitabilitas}

Hasil perhitungan statistik secara parsial yang terlihat pada tabel 18 adalah sesuai dengan pernyataan hipotesis bahwa perputaran aktiva tetap sebagai variabel independen berpengaruh dan signifikan terhadap profitabilitas, dengan nilai koefisien 3,473 dan dengan nilai signifikansi $0,001<0,05$, artinya perputaran aktiva tetap berpengaruh positif dan signifikan terhadap profitabilitas. Hasil penelitian menyatakan bahwa $\mathbf{H}_{4}$ diterima.

\section{Uji F (Uji Simultan)}

Tabel 9. Hasil Uji F (Simultan)

Berdasarkan tabel diperoleh $\mathrm{F}$ hitung sebesar 4,855 dan signifikansi sebesar $0.003^{\mathrm{b}}$. Nilai signifikansi lebih kecil dari 0.05, hal ini menunjukkan bahwa hipotesis diterima dan Perputaran Kas, Perputaran Piutang, Perputaran Persediaan dan Perputaran Aktiva Tetap berpengaruh dan signifikan terhadap Profitabilitas pada Perusahaan Manufaktur Sektor Industri dan Kimia yang terdaftar di Bursa Efek Indonesia (BEI) periode Tahun 2016 - 2019.

\section{Koefisien Determinasi $\left(\mathbf{R}^{2}\right)$}

Tabel 10. Hasil Uji Koefisien Determinasi $\left(\mathrm{R}^{2}\right)$ 


\begin{tabular}{|c|c|c|c|c|}
\hline \multicolumn{5}{|c|}{ Model Summary } \\
\hline Model & R & $\begin{array}{c}\mathrm{R} \\
\text { Square }\end{array}$ & $\begin{array}{l}\text { Adjusted R } \\
\text { Square }\end{array}$ & $\begin{array}{l}\text { Std. Error of } \\
\text { the Estimate }\end{array}$ \\
\hline 1 &, $558^{\mathrm{a}}$ & ,311 & ,247 &, 0260622 \\
\hline $\begin{array}{l}\text { ITO } \\
\text { b. De }\end{array}$ & $\begin{array}{l}, C \\
\text { hde }\end{array}$ & $\begin{array}{l}\text { (X1) } \\
\text { Jariak }\end{array}$ & $(X<$ & (2). \\
\hline
\end{tabular}

Dalam tabel 10 diketahui pula nilai koefisien determinasi atau R Square adalah 0,311 . Nilai $R$ Square 0,311 ini berasal dari pengkuadratan nilai koefisien korelasi atau "R", yaitu $0,558^{\mathrm{a}} \times 0,558^{\mathrm{a}}=0,311$. Besarnya angka koefisien determinasi ( $\mathrm{R}$ Square) adalah 0,311 atau sama dengan $31,1 \%$. Angka tersebut mengandung arti bahwa variabel Perputaran Kas, Perputaran Piutang, Perputaran Persediaan dan Perputaran Aktiva Tetap secara simultan (bersama-sama) berpengaruh terhadap variabel Profitabilitas (Y) sebesar 31,1\%. Sedangkan sisanya $(100 \%-31,1 \%=$ $68,9 \%$ ) dipengaruhi oleh variabel lain di luar persamaan regresi ini atau variabel lain yang tidak diteliti.

\section{Pembahasan Hasil Penelitian \\ Hasil Pengaruh Perputaran Kas, Perputaran Piutang, Perputaran}

Dari Hasil Pengujian atas pengaruh Perputaran Kas, Perputaran Piutang Usaha dan Perputaran Persediaan diperoleh persamaan

$\mathrm{Y}=\alpha+\beta 1 \mathrm{X} 1+\beta 2(\mathrm{X} 1 . \mathrm{X} 2)+\beta 3(\mathrm{X} 1$. $\mathrm{X} 3)+\beta 4(\mathrm{X} 1 . \mathrm{X} 3)+\varepsilon$

$\mathrm{Y}=0,008-0,002 \mathrm{X} 1+0,000 \mathrm{X} 2+0,006$ $\mathrm{X} 3+0,023 \mathrm{X} 4+\mathrm{e}$

Perputaran kas berpengaruh negatif terhadap Profitabilitas pada Perusahaan Manufaktur Sektor Industri dan Kimia
Jurnal Akuntansi dan Bisnis Krisnadwipayana Volume 8 No. 2 (Mei - Agustus) 2021

\section{Persediaan dan Perputaran Aktiva Tetap Terhadap Profitabilitas Secara Simultan}

Berdasarkan hasil analisis data di atas diketahui $\mathrm{F}$ hitung sebesar 4,855 dan nilai signifikansi sebesar sebesar $0.003^{\mathrm{b}}<$ 0,05. Maka artinya Perputaran Kas, Perputaran Piutang, Perputaran Persediaan dan Perputaran Aktiva Tetap secara simultan berpengaruh dan signifikan terhadap Profitabilitas pada Perusahaan Manufaktur Sektor Industri dan Kimia yang terdaftar di Bursa Efek Indonesia (BEI) Periode Tahun 2016 - 2019.

Nilai Adjusted $R^{2}$ sebesar 0,311. Hal ini menunjukkan bahwa Profitabilitas yang dipengaruhi oleh Perputaran Kas, Perputaran Piutang, Perputaran Persediaan dan Perputaran Aktiva Tetap sebesar $31,1 \%$ sedangkan sisanya $68,9 \%$ dipengaruhi oleh variabel lain di luar penelitian ini.

\section{Hasil Pengaruh Perputaran Kas,} Perputaran Piutang, Perputaran Persediaan, dan Perputaran Aktiva Tetap Terhadap Profitabilitas Secara Parsial

yang terdaftar di Bursa Efek Indonesia (BEI) periode 2016 - 2019. Hasil analisis data hipotesis pertama diketahui bahwa nilai t-hitung sebesar -2,066 dan dengan nilai signifikansi $0,045<0,05$, sehingga dapat disimpulkan bahwa perputaran kas berpengaruh negatif dan signifikan terhadap profitabilitas.

Perputaran Piutang berpengaruh negatif terhadap Profitabilitas pada Perusahaan Manufaktur Sektor Industri dan Kimia yang terdaftar di Bursa Efek Indonesia (BEI) periode 2016 - 2019. Hasil analisis 
Printed ISSN : $2406-7415$

Electronic ISSN : $2655-9919$

DOI: http://dx.doi.org/10.35137/jabk.v8i2.568

data hipotesis pertama diketahui bahwa nilai $t$ hitung sebesar $-0,160$ dan dengan nilai signifikansi $0,873>0,05$, sehingga dapat disimpulkan bahwa perputaran piutang berpengaruh negatif dan tidak signifikan terhadap profitabilitas.

Perputaran Persediaan berpengaruh positif terhadap Profitabilitas pada Perusahaan Manufaktur Sektor Industri dan Kimia yang terdaftar di Bursa Efek Indonesia (BEI) periode 2016 - 2019. Hasil analisis data hipotesis pertama diketahui bahwa nilai $\mathrm{t}$ hitung sebesar 2,361 dan dengan nilai signifikansi $0,023<0,05$, sehingga dapat disimpulkan bahwa perputaran persediaan berpengaruh positif dan signifikan terhadap profitabilitas.

Perputaran Aktiva Tetap berpengaruh positif terhadap Profitabilitas pada Perusahaan Manufaktur Sektor Industri dan Kimia yang terdaftar di Bursa Efek Indonesia (BEI) periode 2016 - 2019. Hasil analisis data hipotesis pertama diketahui bahwa nilai $\mathrm{t}$ hitung sebesar 3,473 dan dengan nilai signifikansi 0,001 $<0,05$, sehingga dapat disimpulkan bahwa perputaran aktiva tetap berpengaruh positif dan signifikan terhadap profitabilitas.

\section{KESIMPULAN DAN SARAN}

\section{Kesimpulan}

1. Berdasarkan hasil uji penelitian secara parsial, perputaran kas berpengaruh negatif dan signifikan terhadap profitabilitas pada Perusahaan Manufaktur Sektor Industri dan Kimia
Jurnal Akuntansi dan Bisnis Krisnadwipayana Volume 8 No. 2 (Mei - Agustus) 2021 yang terdaftar di Bursa Efek Indonesia (BEI) periode 2016 - 2019. Hasil analisis data hipotesis pertama diketahui bahwa nilai t-hitung sebesar 2,066 dan dengan nilai signifikansi $0,045<0,05$, sehingga dapat disimpulkan bahwa perputaran kas berpengaruh negatif dan signifikan terhadap profitabilitas. Berdasarkan hipotesis pertama, variabel Perputaran Kas menunjukkan terdapat pengaruh dan signifikan terhadap Profitabilitas sehingga $\mathrm{H} 1$ diterima. Karena Hipotesa (H1) diterima, maka Perputaran Kas dapat digunakan untuk memprediksi Profitabilitas pada Perusahaan Manufaktur Sektor Industri dan Kimia yang terdaftar di Bursa Efek Indonesia (BEI) periode Tahun 2016 - 2019.

2. Berdasarkan hasil uji penelitian secara parsial, perputaran piutang berpengaruh negatif dan tidak signifikan terhadap profitabilitas pada Perusahaan Manufaktur Sektor Industri dan Kimia yang terdaftar di Bursa Efek Indonesia (BEI) periode 2016 - 2019. Hasil analisis data hipotesis pertama diketahui bahwa nilai t hitung sebesar 0,160 dan dengan nilai signifikansi $0,873>0,05$, sehingga dapat disimpulkan bahwa perputaran piutang berpengaruh negatif dan tidak signifikan terhadap profitabilitas. Berdasarkan hipotesis kedua, variabel perputaran piutang menunjukkan terdapat pengaruh negatif dan tidak signifikan terhadap Profitabilitas sehingga H2 ditolak. Karena Hipotesa (H2) ditolak, maka Perputaran Piutang tidak dapat digunakan untuk 
Printed ISSN : $2406-7415$

Electronic ISSN : $2655-9919$

DOI: http://dx.doi.org/10.35137/jabk.v8i2.568

memprediksi Profitabilitas pada Perusahaan Manufaktur Sektor Industri dan Kimia yang terdaftar di Bursa Efek Indonesia (BEI) periode Tahun 2016 2019.

3. Berdasarkan hasil uji penelitian secara parsial, perputaran persediaan berpengaruh positif dan signifikan terhadap profitabilitas pada Perusahaan Manufaktur Sektor Industri dan Kimia yang terdaftar di Bursa Efek Indonesia (BEI) periode 2016 - 2019. Hasil analisis data hipotesis pertama diketahui bahwa nilai $\mathrm{t}$ hitung sebesar 2,361 dan dengan nilai signifikansi $0,023<0,05$, sehingga dapat disimpulkan bahwa perputaran persediaan berpengaruh positif dan signifikan terhadap profitabilitas. Berdasarkan hipotesis ketiga, variabel perputaran persediaan menunjukkan terdapat pengaruh dan signifikan terhadap profitabilitas sehingga H3 diterima. Karena Hipotesa (H3) diterima, maka Perputaran Persediaan dapat digunakan untuk memprediksi Profitabilitas pada Perusahaan Manufaktur Sektor Industri dan Kimia yang terdaftar di Bursa Efek Indonesia (BEI) periode Tahun 2016 - 2019.

4. Berdasarkan hasil uji penelitian secara parsial, perputaran aktiva tetap berpengaruh positif dan signifikan terhadap profitabilitas pada Perusahaan Manufaktur Sektor Industri dan Kimia yang terdaftar di Bursa Efek Indonesia (BEI) periode 2016 - 2019. Hasil analisis data hipotesis pertama diketahui bahwa nilai t hitung sebesar 3,473 dan dengan nilai signifikansi
Jurnal Akuntansi dan Bisnis Krisnadwipayana Volume 8 No. 2 (Mei - Agustus) 2021 $0,001<0,05$, sehingga dapat disimpulkan bahwa perputaran aktiva tetap berpengaruh positif dan signifikan terhadap profitabilitas. Berdasarkan hipotesis keempat, variabel Perputaran aktiva tetap menunjukkan terdapat pengaruh dan signifikan terhadap Profitabilitas sehingga $\mathrm{H} 4$ diterima. Karena Hipotesa (H4) diterima, maka Perputaran Aktiva Tetap dapat digunakan untuk memprediksi Profitabilitas pada Perusahaan Manufaktur Sektor Industri dan Kimia yang terdaftar di Bursa Efek Indonesia (BEI) periode Tahun 2016 2019.

5. Hasil analisis Uji $F$ pada penelitian ini menunjukkan bahwa Perputaran Kas, Perputaran Piutang, Perputaran Persediaan dan Perputaran Aktiva Tetap secara simultan berpengaruh dan signifikan terhadap Profitabilitas pada Perusahaan Manufaktur Sektor Industri dan Kimia yang terdaftar di Bursa Efek Indonesia (BEI) Periode Tahun 2016 2019. Hal ini ditunjukkan oleh nilai $F$ hitung sebesar 4,855 dan nilai signifikansi sebesar $0,003 \mathrm{~b}$. Nilai signifikansi lebih kecil dari 0,05 sehingga H5 diterima.

\section{Saran}

1. Untuk penelitian selanjutnya, sebaiknya menambah atau menggunakan variabel bebas lainnya yang dimana hal tersebut bisa mengembangkan penelitian ini untuk lebih mengetahui informasi yang dapat mempengaruhi Profitabilitas pada 
Printed ISSN : $2406-7415$

Electronic ISSN : $2655-9919$

DOI: http://dx.doi.org/10.35137/jabk.v8i2.568

Perusahaan dan dapat menjadi pertimbangan pada perusahaan dalam mengambil keputusan.

2. Bagi pembaca agar dapat mengembangkan penelitian ini. Dan sehubungan banyaknya perusahaaan yang terdaftar dalam Bursa Efek Indonesia. Sebaiknya perusahaan yang dijadikan objek dalam penelitian tidak hanya terbatas pada Perusahaan Manufaktur Sektor Industri Dasar dan Kimia yang Terdaftar di Bursa Efek Indonesia (BEI). Agar dapat memberikan referensi kepada pihakpihak yang ingin menanamkan modalnya untuk pengambilan keputusan investasi yang lebih baik.

3. Agar perusahaan hendaknya lebih memperhatikan kembali pengelolaan piutang yang dimilikinya dengan lebih meningkatkan perputaran piutang yang tidak dapat ditagih dalam jangka waktu yang relatif singkat atau lamanya penagihan piutang semakin panjang, sehingga perusahaan butuh waktu yang lama untuk menunggu dana yang tersimpan dalam bentuk piutang untuk dapat dicairkan menjadi kas. Oleh karena itu perusahaan harus dapat melakukan pengelolaan penjualan dengan baik untuk mencegah timbulnya kerugian.

\section{DAFTAR PUSTAKA}

Andari, Y. R. A. R. A. (2016). Pengaruh Perputaran Barang Jadi, Arus Kas, Piutang dan Aktiva Tetap Terhadap
Jurnal Akuntansi dan Bisnis Krisnadwipayana Volume 8 No. 2 (Mei - Agustus) 2021

Profitabilitas pada Perusahaan Perdagangan Eceran yang Terdaftar di BEI Periode 2009-2014. Journal Of Accounting, 2(2).

Anwar, M. (2019). Dasar-dasar Manajemen Keuangan Perusahaan (1st ed.). Jakarta: Kencana.

Apriliasari, N. (2018). Pengaruh Perputaran Kas, Perputaran piutang, Perputaran Persediaan dan Perputaran Aktiva Tetap terhadap Profitabilitas pada Perusahaan Food and Beverages yang Terdaftar di Bursa Efek Indonesia (BEI) Periode 2012-2017. Artikel Skripsi.

Arifin, A. Z. (2018). Manajemen Keuangan. Yogyakarta: Zahir Publishing.

Baridwan, Z. (2015). Intermediate Accounting (8th ed.). Yogyakarta: BPFE Yogyakarta.

Boedijoewono, N. (2001). Pengantar Statistik Ekonomi Dan Perusahaan (2nd ed.). Yogyakarta: Revisi Unit penerbit Dan Percetakan AMP YKPN.

Bulin, S. A. B. S. M. H. (2016). Impact of working capital management on firm's profitability. International Journal of Accounting \& Business Management, 4(2).

CR, Sathyamoorthi. Mapharing, Mogotsinyana. Selinkie, P. (2018). The Impact of Working Capital Management on Profitability: Evidence from the Listed Retail Stores in Botswana. Applied Finance and Accounting, 4(1).

Darya, I. G. P. (2019). Akuntansi Manajemen. Ponorogo: Uwais Inspirasi Indonesia.

Farooq, U. (2019). Impact of Inventory Turnover on the Profitability of NonFinancial Sector Firms in Pakistan. Journal of Finance and Accounting Research, 1(1). 
DOI: http://dx.doi.org/10.35137/jabk.v8i2.568

Ghozali, I. (2018). Aplikasi Analisis Multivariate dengan Program IBM SPSS 25 (9th ed.). Semarang: Badan Penerbit Universitas Diponegoro.

Haryanti, C. S. (2014). Analisis Perbandingan Laporan Keuangan Untuk Menilai Kinerja Keuangan Pada Perusahaan Telekomunikasi ( Studi Kasus BEI ). 1(1), 52-86.

Hery. (2015). Pengantar Akuntansi (Comprehens). Jakarta: PT. Grasindo.

Hery. (2017a). Analisis Laporan Keuangan (2nd ed.; Adipramono, ed.). Bandung: PT. Grasindo.

Hery. (2017b). Balanced Scorecard for Business. Jakarta: PT Grasindo.

Husnan, S. dan E. P. (2015). Dasar-Dasar Manajemen Keuangan (7th ed.). Yogyakarta: UPP STIM YKPN.

Ingga, I. (2017). Akuntansi Manajemen: Implementasi dalam Kasus Indonesia. Yogyakarta: Penerbit Deepublish.

Ismail. (2015). Akuntansi Bank: Teori dan Aplikasi dalam Rupiah (Revisi). Jakarta: Prenada Media.

Jakpar, S. Tinggi, M. Siang, TK. Myint, KT. Sadique, M. (2017). Working Capital Management and Profitability: Evidence from Manufacturing Sector in Malaysia. Journal of Business \& Financial Affairs, 6(2).

Jumingan. (2014). Analisis Laporan Keuangan. Jakarta: Bumi Aksara.

Kariyoto. (2017). Analisa Laporan Keuangan. Malang: Universitas Brawijaya Press.

Kasmir. (2015). Analisis Laporan Keuangan (8th ed.). Jakarta: PT. Raja Grafindo Persada.

Kasmir. (2016). Pengantar Manajemen Keuangan (2nd ed.). Jakarta: Prenada Media.

Koesmowidjojo, S. R. . (2017). Balanced Scored: Model Pengukuran Kinerja Organisasi Dengan Empat Perspektif.
Jurnal Akuntansi dan Bisnis Krisnadwipayana Volume 8 No. 2 (Mei - Agustus) 2021 Jakarta: Raih Asa Sukses (Penebar Swadaya Group).

Mburu, J. M. (2013). The Relationship between inventory turnover and financial performance of Supermarkets in Kenya. Unpublished MBA Project.

Muhammad, Hussain. Rehman, Ashfaq U. Waqas, M. (2016). The Relationship between Working Capital Management and Profitability: A Case Study of Tobacco Industry of Pakistan. Journal of Asian Finance, Economics and Busines, 3(2).

Munawir. (2016). Analisis Laporan Keuangan (4th ed.). Yogyakarta: Liberty.

Nurafika, R. A. (2018). Perputaran Persediaan Terhadap Profitabilitas Padaperusahaan Semen the Influence of Cash Turnover, Receivable Turnover, Inventory Turnover To Profitability. Jurnal Akuntansi Dan Bisnis.

Obeidat, M. I. dan A. J. (2016). The Impact of Working Capital Management on the Profitability of Construction Equipment Firms: Evidence from Listed Construction Equipment Firms in Abu Dhabi Stock Exchange. Journal of Accounting and Finance, 16(8).

Pratama, F. dan D. P. (2017). Pengaruh Perputaran Kas, Perputaran Piutang, dan Perputaran Persediaan terhadap Profitabilitas pada Perusahaan Property dan Real Estate yang terdaftar di Bursa Efek Indonesia Periode 2011-2015. Jurnal Ilmiah Akuntansi, 1(4).

Prihadi, T. (2019). Analisis Laporan Keuangan. Jakarta: Gramedia Pustaka Media.

Pujiyanti, F. (2015). Rahasia Cepat Menguasai Laporan Keuangan Khusus Dengan Akuntansi Dasar: 
DOI: http://dx.doi.org/10.35137/jabk.v8i2.568

Cara Terbaik dan Tercepat Menguasai Keuangan. Padang: Lembar Pustaka Media.

Purwaji, A. W. dan H. S. L. (2016). Pengantar Akuntansi (2nd ed.). Jakarta: Salemba Empat.

Purwanti, T. (2019). An Analysis of Cash and Receivables Turnover Effect Towards Company Profitability. International Journal of Seocology, 1(1).

Riyanto, B. (2014). Dasar-Dasar Pembelanjaan Perusahaan (4th ed.). Yogyakarta: BPFE Yogyakarta.

Rudianto. (2012). Pengantar Akuntansi: Konsep \& Teknik Penyusunan Laporan Keuangan Adaptasi IFRS. Jakarta: Penerbit Erlangga.

Sabo, Muhammad. Rabi’U, Saminu Jibril. Usman, Sani. Fatima, Bello Ibrahim. Tjjani, abibu A. (2015). The Effect of Working Capital Management on Corporate Profitability: Evidence from Nigerian Food Product Firms. Applied Finance and Accounting, 1(2).

Sariningsih, N. (2018). PENGARUH PERPUTARAN KAS, PERPUTARAN PIUTANG DAN PERPUTARAN PERSEDIAAN TERHADAP PROFITABILITAS (Studi Pada Perusahaan Property dan Realestat yang Terdaftar di Bursa Efek Indonesia Periode 2010-2016). Jurnal Buana Akuntansi, 3(1). https://doi.org/10.36805/akuntansi.v3i 1.233

Sartono, A. (2015). Manajemen Keuangan Teori dan Aplikasi (4th ed.). , dan Inventory Turnover Terhadap Return on Asset Perusahaan Properti yang terdaftar di BEI Periode 2015-2017. E-JRA, 8(4).

Widyatuti, M. (2017). Analisa Kritis
Jurnal Akuntansi dan Bisnis Krisnadwipayana Volume 8 No. 2 (Mei - Agustus) 2021 Yogyakarta: BPFE Yogyakarta.

Shatu, Y. P. (2016). Kuasai Detail Akuntansi Perkantoran (N. Sari, ed.). Jakarta: Pustaka Ilmu Semesta.

Subramanyam, K. . dan J. J. W. (2014). Analisis Laporan Keuangan (10th ed.). Jakarta: Salemba Empat.

Sugeng, B. (2019). Manajemen Keuangan Fundamental. Sleman: Penerbit Deepublish.

Sugiono, A. (2016). Panduan Praktis Dasar Analisa Laporan Keuangan (Revisi). Jakarta: PT. Grasindo.

Sugiyono. (2010). Statistika untuk Penelitian. Bandung: Alfabeta.

Sugiyono. (2012). Metode Penelitian Pendidikan Pendekatan Kuantitatif Kualitatif dan $R \& D$. Bandung: Alfabeta.

Suharli, M. (2006). Akuntansi Untuk Bisnis Jasa Dan Dagang. Yogyakarta: Graha Ilmu.

Suhartiningsih, D. (2012). Pengaruh Perputaran Piutang, Perputaran Persediaan, Perputaran Aktiva Tetap, dan Perputaran Total Aktiva Terhadap Profitabilitas Pada Perusahaan Makanan dan Minuman Yang Terdaftar Di BEI Periode 20062009. Artikel Ilmiah Akuntansi.

Suminar, M. T. (2015). Pengaruh Perputaran Persediaan, Perputaran Piutang, dan Perputaran Kas terhadap Profitabilitas pada Perusahaan Sektor Industri Barang Konsumsi yang Terdaftar di BEI Periode 2008-2013. Journal of Accounting, 1(1).

Umayta, I. K. N. D. A. (2019). Pengaruh Cash Turnover, Receivable Turnover Laporan Keuangan. Surabaya: Jakad Media Nusantara.

Wijaya, D. (2017). Manajemen Keuangan Konsep dan Penerapannya. Jakarta: Mitra Wacana Media 
Printed ISSN : $2406-7415$

Electronic ISSN : 2655 - 9919

DOI: $\underline{\text { http://dx.doi.org/10.35137/jabk.v8i2.568 }}$

Jurnal Akuntansi dan Bisnis Krisnadwipayana Volume 8 No. 2 (Mei - Agustus) 2021 